Azari Mehrdad Mohammed Ali, Morozov A. L. Parodontoprotective action of oral applications of soy isoflavons in rats after orthodontic operation on the background of experimental diabetes mellitus. Journal of Education, Health and Sport. 2019;9(11):185-193. eISSN 23918306. DOI http://dx.doi.org/10.5281/zenodo.3964258

https://apcz.umk.pl/czasopisma/index.php/JEHS/article/view/JEHS.2019.09.11.015

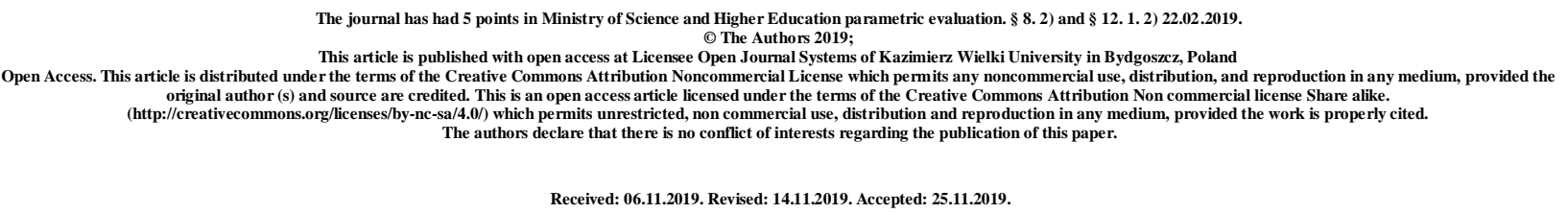

UDK 616.31:615.37:616.179:379.008

\title{
PARODONTOPROTECTIVE ACTION OF ORAL APPLICATIONS OF SOY ISOFLAVONS IN RATS AFTER ORTHODONTIC OPERATION ON THE BACKGROUND OF EXPERIMENTAL DIABETES MELLITUS
}

\author{
Azari Mehrdad Mohammed Ali ${ }^{1}$, A. L. Morozov ${ }^{2}$ \\ ${ }^{1}$ Odessa National Medical University \\ ${ }^{2}$ The Federal State Autonomous Educational Institution for Higher Education \\ "V. I. Vernadsky Crimean Federal University" \\ Department of Stomatology and Orthodontic, Medical Academy named after \\ S. I. Georgievsky (Simferopol, under Russian Federation jurisdiction) \\ flavan.ua@gmail.com
}

\section{Abstract}

Background. To determine the periodontoprotective effect of soy isoflavones in rats after orthodontic surgery on the background of diabetes mellitus.

Methods. In rats, type 1 diabetes was reproduced with aloxane (intraperitoneally at a dose of $100 \mathrm{mg} / \mathrm{kg}$ once). From day 12, rats were fitted with orthodontic springs. One of these groups of rats received oral gel applications with soy isoflavones from the first day of the experiment at a dose of $0.5 \mathrm{ml}$ daily for 34 days. The activity of elastase, catalase, urease, lysozyme and the content of malondialdehyde (MDA) were determined in the gum. In the alveolar process of the 
lower jaw, the activity of alkaline (alkaline phosphatase) and acid (APH) phosphatases, the content of calcium and protein were determined. The antioxidant-prooxidant index (API) was calculated by the ratio of catalase activity and MDA content, the degree of dysbiosis was calculated by the ratio of the relative activities of urease and lysozyme, the mineralizing index (MI) was calculated by the ratio of alkaline phosphatase and APH activity, and the degree of mineralization (DM) was calculated by the ratio of calcium and protein.

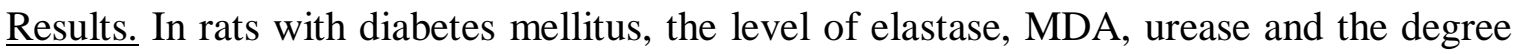
of dysbiosis increased with a decrease in the API index and lysozyme activity. Orthodontic surgery showed a certain tendency to normalize these parameters, while the application of a gel containing soy isoflavones completely normalized all indicators. In the bone tissue of periodontium in rats with diabetes mellitus, the activity of alkaline phosphatase and MI decreased, but the activity of APH increased. Orthodontic surgery significantly increased the activity of alkaline phosphatase, slightly changing the activity of APH and the index of API. Application of the gel with isoflavones completely normalized the activity of phosphatases, MI and significantly increased the degree of mineralization of bone tissue.

Conclusion. Rats with type 1 diabetes develop periodontitis. Orthodontic surgery does not exacerbate the pathological condition, showing even a slight tendency to normalize. Oral applications of a gel containing soy isoflavones have a periodontoprotective effect, normalizing all biochemical parameters of the gums and bone periodontal tissue.

Key words: periodontal disease; diabetes mellitus; orthodontics; inflammation; dysbiosis; isoflavones; oral gels.

\section{INTRODUCTION}

With diabetes in the oral cavity develops dysbiosis, which aggravates the course of pathological processes in the periodontium [1-3]. Against this background, carrying out orthodontic, orthopedic and any surgical operations is fraught with the development of possible complications [4-7].

However, in our previous work [8] it was shown that orthodontic manipulations in rats with type 1 diabetes mellitus have a rather positive effect: they reduce the degree of dysbiosis and inflammation in the gum, and to a certain extent increase the mineralizing index of periodontal bone tissue. 
The purpose of this study was to determine the periodontoprotective effect of the preparation of soy isoflavones "Exo" under experimental orthodontic surgery in rats with diabetes mellitus.

The drug "EXSO" is a dry extract from soybean beans containing isoflavones genistin and daidzin, galactosucrose raffinose and stachyose, inhibitor proteases Bauman-Birk [9]. It is produced in Ukraine by the company NPA "Odessa Biotechnology" in tableted form [9]. The drug "EXSO" has found wide application as an osteoprotective agent in dentistry and orthodontdic [9].

In this work, a mucosal-adhesive phyto-gel "EXSO" containing 10\% "EXSO" in a 4\% gel of carboxymethyl cellulose, sodium salt [10] was used.

\section{MATERIAL AND RESEARCH METHODS}

The experiments were carried out on 25 white Wistar rats (males, 3 months old, initial live weight $125 \pm 7 \mathrm{~g}$ ) distributed into 4 groups: the first (7 rats) served as a control, the 2nd (8 rats), the 3rd (5 rats) and 4th (5 rats) received a single injection (in/peritoneal) of alloxan at a dose of $100 \mathrm{mg} / \mathrm{kg}$ in order to reproduce type 1 diabetes mellitus. Rats of the 3rd and 4th groups, starting from the 12th day of the experiment, were fixed in the mouth with orthodontic springs [11]. Rats of the 4th group received daily oral applications of the gel "EXSO" in a dose of $0.5 \mathrm{ml}$ per rat from the first day of the experiment.

Euthanization of animals was performed on the 35th day of the experiment under thiopental anesthesia $(20 \mathrm{mg} / \mathrm{kg})$ by total bloodletting from the heart. The gum was excised and the alveolar process of the lower jaw was allocated.

In the gum homogenate, the level of inflammatory markers was determined [12]: elastase activity and malonic dialdehyde content (MDA), urease activity (microbial seeding indicator) [13], lysozyme activity (indicator of non-specific immunity status) [13] and antioxidant catalase enzyme activity [12]. The antioxidant-prooxidant index of API was calculated from the ratio of catalase activity and MDA content [12], and the degree of dysbiosis according to Levitsky [13] was calculated from the ratio of relative activities of urease and lysozyme.

In the homogenate of the bone tissue of the alveolar process, the activity of alkaline (AlP) and acidic (AcP) phosphatases [14], protein [14] and calcium [14] was determined. The mineralizing index of MI was calculated from the ratio of AlP/AcP [15], and the degree of mineralization of bone tissue (DM) was calculated from the ratio of calcium and protein [15]. 
The results of the studies were subjected to a standard statistical treatment [16].

\section{RESULTS AND DISCUSSION}

Table 1 shows the results of determining the level of markers of inflammation in the gums of the rats. From these data it can be seen that the oral applications of Exo gel reduce the activity of elastase, which is significantly increased in diabetes and after orthopedic surgery, which indicates the anti-inflammatory effect of the drug.

Table 1. Effect of "EXSO" gel on the level of markers of inflammation in the gums of the rats with diabetes mellitus, who received orthodontic treatment

\begin{tabular}{|c|l|c|c|}
\hline $\begin{array}{c}\text { Number } \\
\text { of group }\end{array}$ & \multicolumn{1}{|c|}{ Groups } & Elastasa, mc-kat/kg & MDA, mmol/kg \\
\hline 1 & Control & $34,5 \pm 1,5$ & $13,9 \pm 1,6$ \\
\hline 2 & Type 1 diabetes mellitus (DM1) & $\begin{array}{c}40,8 \pm 1,9 \\
\mathrm{p}<0,05\end{array}$ & $\begin{array}{c}22,9 \pm 1,5 \\
\mathrm{p}<0,01\end{array}$ \\
\hline 3 & DM1 + Orthodontic treatment & $38,9 \pm 2,3$ & $16,7 \pm 1,4$ \\
& (OT) & $\mathrm{p}>0,05 ; \mathrm{p}_{1}>0,3$ & $\mathrm{p}>0,1 ; \mathrm{p}_{1}>0,05$ \\
\hline 4 & DM1 + OT + gel «EXSO» & $32,4 \pm 1,7$ & $14,1 \pm 1,2$ \\
& & $\mathrm{p}>0,3 ; \mathrm{p}_{1}<0,05$ & $\mathrm{p}>0,5 ; \mathrm{p}_{1}<0,05$ \\
& & $\mathrm{p}_{2}<0,05$ & $\mathrm{p}_{2}>0,05$ \\
\hline
\end{tabular}

Notes: $\mathrm{p}$ - in comparison with gr. № 1; $\mathrm{p}_{1}$ - in comparison with gr. № 2; $\mathrm{p}_{2}-$ in comparison with gr. № 3.

Table 2 shows the results of determining the activity of urease and lysozyme in the gum. Appliques gel "EXSO" fully normalize both indicators, indicating the elimination of increased microbial contamination and the normalization of the level of nonspecific immunity.

Table 2. Effect of "EXSO" gel on the activity of urease and lysozyme in the gums of the rats with diabetes mellitus, who received orthodontic treatment

\begin{tabular}{|c|l|c|c|}
\hline $\begin{array}{c}\text { Number } \\
\text { of group }\end{array}$ & \multicolumn{1}{|c|}{ Groups } & Urease, mc-kat/kg & Lysozim units/kg \\
\hline 1 & Control & $0,95 \pm 0,24$ & $196 \pm 14$ \\
\hline 2 & Type 1 diabetes mellitus (DM1) & $\begin{array}{c}1,82 \pm 0,29 \\
\mathrm{p}<0,05\end{array}$ & $\begin{array}{c}167 \pm 16 \\
\mathrm{p}>0,1\end{array}$ \\
\hline 3 & DM1 + Orthodontic treatment & $1,18 \pm 0,33$ & $184 \pm 27$ \\
& (OT) & $\mathrm{p}>0,3 ; \mathrm{p}_{1}>0,05$ & $\mathrm{p}>0,3 ; \mathrm{p}_{1}>0,3$ \\
\hline 4 & DM1 + OT + gel «EXSO» & $0,94 \pm 0,17$ & $214 \pm 12$ \\
& & $\mathrm{p}>0,8 ; \mathrm{p}_{1}<0,05$ & $\mathrm{p}>0,3 ; \mathrm{p}_{1}<0,05$ \\
& & $\mathrm{p}_{2}>0,3$ & $\mathrm{p}_{2}>0,1$ \\
\hline
\end{tabular}

Notes: see tab. 1. 
The degree of gingival dysbiosis calculated from these parameters is shown in Fig. 1, from which it can be seen that the applications of the gel "EXSO" completely normalize the degree of dysbiosis.

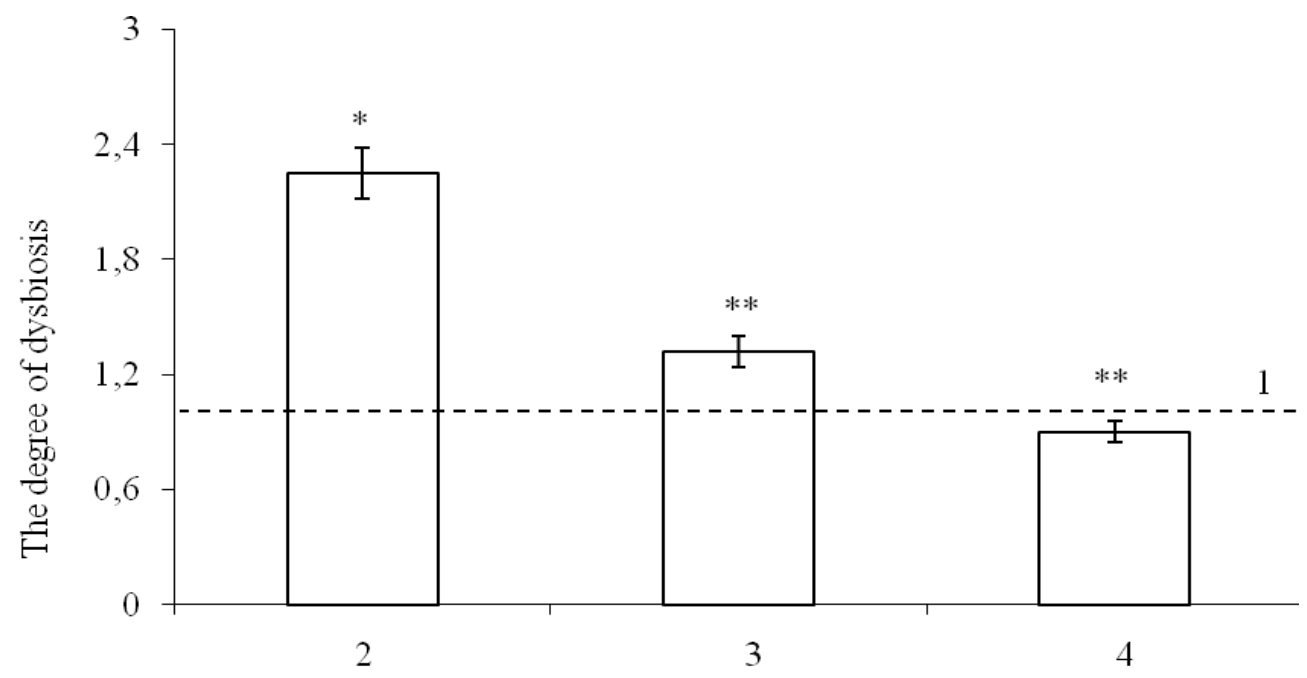

Fig. 1. Effect of "EXSO" gel on the degree of dysbiosis in the gums of rats with diabetes, who received orthodontic treatment

(1 - control; 2 - DM1; 3 - DM1 + orthodontic treatment (OT); 4 - DM1 + OT + gel "EXSO") $*_{-} \mathrm{p}<0,05$ in comparison with gr. $1 ; * *-\mathrm{p}<0,05$ in comparison with gr. 2

Table 3 presents the results of determining the activity of catalase and the API index in the gingiva. It can be seen that the "EXSO" gel applications completely normalize both indices.

Table 3. Effect of "EXSO" gel on catalase activity and antioxidant prooxidant index (API) in the gums of the rats with diabetes mellitus, who received orthodontic treatment

\begin{tabular}{|c|l|c|c|}
\hline $\begin{array}{c}\text { Number } \\
\text { of group }\end{array}$ & \multicolumn{1}{|c|}{ Groups } & Catalase mkat/kg & API, units. \\
\hline 1 & Control & $6,3 \pm 0,3$ & $4,53 \pm 0,38$ \\
\hline 2 & Type 1 diabetes mellitus (DM1) & $6,8 \pm 0,3$ & $2,97 \pm 0,29$ \\
& & $\mathrm{p}>0,05$ & $\mathrm{p}<0,05$ \\
\hline 3 & DM1 + Orthodontic treatment & $6,4 \pm 0,2$ & $3,53 \pm 0,37$ \\
& (OT) & $\mathrm{p}>0,5 ; \mathrm{p}_{1}>0,1$ & $\mathrm{p}>0,1 ; \mathrm{p}_{1}>0,05$ \\
\hline 4 & DM1 + OT + gel «EXSO» & $6,9 \pm 0,2$ & $4,89 \pm 0,35$ \\
& \multicolumn{2}{|c}{$\mathrm{p}>0,05 ; \mathrm{p}_{1}>0,3$} & $\mathrm{p}>0,3 ; \mathrm{p}_{1}<0,05$ \\
& & $\mathrm{p}_{2}>0,05$ & $\mathrm{p}_{2}>0,05$ \\
\hline
\end{tabular}

Notes: see tab. 1. 
Table 4 presents the results of determining the activity of phosphatases in the bone tissue of the periodontal tissue. It can be seen that the oral applications of the "EXSO" gel increase the activity of alkaline phosphatase and reduce the activity of acid phosphatase, which gave a significant increase in mineralizing activity, as evidenced by a significant increase in the MI index (Fig. 2).

Table 4. Effect of "EXSO" gel on the activity of phosphatases in the bone tissue of periodontal rats with diabetes mellitus, who received orthodontic treatment

\begin{tabular}{|c|l|c|c|}
\hline $\begin{array}{c}\text { Number } \\
\text { of group }\end{array}$ & \multicolumn{1}{|c|}{ Groups } & $\begin{array}{c}\text { Alkaline } \\
\text { phosphatase, mc- } \\
\mathrm{kat} / \mathrm{kg}\end{array}$ & $\begin{array}{c}\text { Acid phosphatase, } \\
\mathrm{mc}-\mathrm{kat} / \mathrm{kg}\end{array}$ \\
\hline 1 & Control & $93,0 \pm 7,2$ & $7,2 \pm 0,8$ \\
\hline 2 & Type 1 diabetes mellitus (DM1) & $\begin{array}{c}55,7 \pm 10,0 \\
\mathrm{p}<0,05\end{array}$ & $\begin{array}{c}10,4 \pm 0,6 \\
\mathrm{p}<0,05\end{array}$ \\
\hline 3 & DM1 + Orthodontic treatment & $90,3 \pm 10,4$ & $9,9 \pm 1,8$ \\
& (OT) & $\mathrm{p}>0,5 ; \mathrm{p}_{1}<0,05$ & $\mathrm{p}>0,05 ; \mathrm{p}_{1}>0,3$ \\
\hline 4 & DM1 + OT + gel «EXSO» & $98,9 \pm 9,2$ & $7,0 \pm 0,6$ \\
& \multicolumn{2}{|c|}{$\mathrm{p}>0,3 ; \mathrm{p}_{1}<0,05$} & $\mathrm{p}>0,5 ; \mathrm{p}_{1}<0,01$ \\
$\mathrm{p}_{2}>0,3$ & $\mathrm{p}_{2}<0,05$ \\
\hline
\end{tabular}

Notes: see tab. 1.

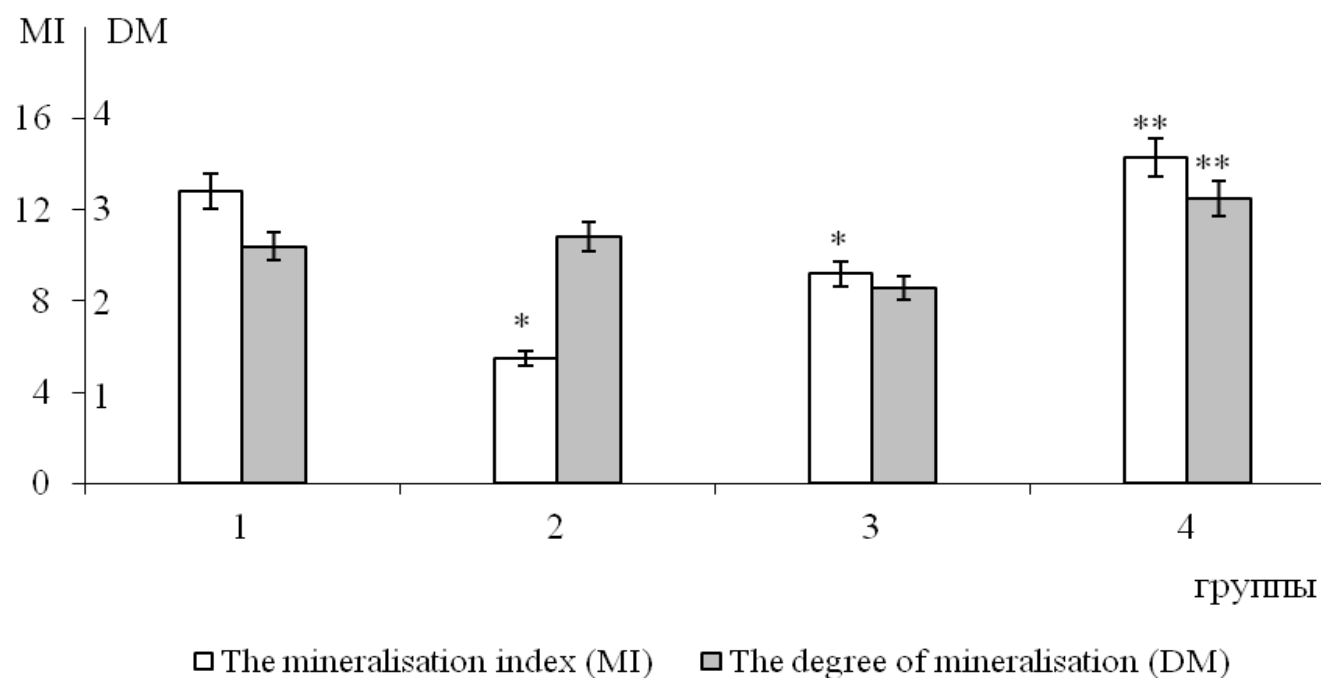

Fig. 2. Effect of "EXSO" gel on the indices of MI and DM in the periodontal bone tissue of rats with diabetes who received orthodontic treatment $(1$ - control; 2 - DM1;

3 - DM1 + orthodontic treatment (OT); 4 - DM1 + OT + gel "EXSO") $*_{-}$p $<0,05$ in comparison with gr. $1 ; * *-p<0,05$ in comparison with gr. 3 
Table 5 shows the results of the determination of protein and calcium in bone tissue. It can be seen that the oral applications of "EXSO" gel significantly increase the calcium content and, consequently, increase the degree of mineralization of bone tissue by $44 \%$ (Fig. 2).

Table 5. Effect of "EXSO" gel on protein and calcium content in bone tissue periodontal rats with diabetes mellitus receiving orthodontic treatment

\begin{tabular}{|c|l|c|c|}
\hline $\begin{array}{c}\text { Number } \\
\text { of group }\end{array}$ & \multicolumn{1}{|c|}{ Groups } & Protein, g/kg & Calcium, g/kg \\
\hline 1 & Control & $24,6 \pm 2,4$ & $62,0 \pm 5,6$ \\
\hline 2 & Type 1 diabetes mellitus (DM1) & $\begin{array}{c}20,7 \pm 1,5 \\
\mathrm{p}>0,05\end{array}$ & $\begin{array}{c}55,6 \pm 3,6 \\
\mathrm{p}>0,3\end{array}$ \\
\hline 3 & DM1 + Orthodontic treatment & $22,9 \pm 1,3$ & $50,0 \pm 9,2$ \\
& (OT) $>0,3 ; \mathrm{p}_{1}>0,1$ & $\mathrm{p}>0,3 ; \mathrm{p}_{1}>0,3$ \\
\hline 4 & DM1 + OT + gel «EXSO» & $21,5 \pm 1,6$ & $67,4 \pm 4,6$ \\
& & $\mathrm{p}>0,2 ; \mathrm{p}_{1}>0,3$ & $\mathrm{p}>0,3 ; \mathrm{p}_{1}<0,05$ \\
& & $\mathrm{p}_{2}>0,3$ & $\mathrm{p}_{2}>0,05$ \\
\hline
\end{tabular}

Notes: see tab. 1.

Thus, the data obtained by us testify to the advisability of using oral applique gel "EXSO" for orthodontic operations against diabetes mellitus. These results are consistent with the data of other authors on the beneficial effect on periodontium "EXSO" in experimental diabetes mellitus $[6,17]$.

It is important that the oral applications of the "EXSO" gel strengthen the mineralizing activity of the periodontal bone tissue, which can significantly expand the indications for its use not only in dentistry, but also in other areas of medicine.

\section{REFERENCES}

1. Sykes LM, Sukha A. Potential risk of serious oral infections in the diabetic patient: a clinical report. J. Proshet. Dent. 2001; 86: 569-573.

2. Mutoh T, Honda E, Matsumoto K. [and others]. Study of oral microflora in diabetes mellitus patients. J. Dent. res. 2000; 79(Spec. is.): 2013.

3. Basov AA, Bykov IM, Melnonyan KI. Changes in immunological reactivity and free radical oxidation processes in the oral fluid in patients with type 2 diabetes mellitus. International Journal of Applied and Fundamental Research. 2014; 2: 31-34. 
4. Fesenko UA, Malygina DA. Influence of diabetes mellitus on clinical and laboratory indices of inflammatory diseases of maxillofacial area in children. Dentist. 2010; 1(139): 32-33.

5. Ota M, Seshima F, Okubo N. [and others]. A collaborative approach to care for patients with periodontitis and diabetes. Bull. Tokyo Dent. Coll. 2013; 54(1): 51-57.

6. Demyanenko SA, Morozov AL, Denga AE. Influence of the experimental orthodontic operation on the periodontal condition in rats with metabolic syndrome. Parodontology. 2017; XXIIIb(4(85): 4-7.

7. Badanov RM. Development of a differentiated approach to the prevention and treatment of prosthetic stomatitis in patients with diabetes mellitus. Odessky medical journal. 2011; 1(123): 36-40.

8. Azari Mehrdad Mohammad Ali. Periodontal condition in rats with experimental diabetes mellitus after orthodontic surgery. Journal of Education, Health and Sport. 2019; 9(10): 246-252.

9. Makarenko OA. How to protect bone tissue. Odessa, KP OGT, 2013: 52.

10. Levitsky AP, Makarenko OA, Selivanskaya IA [and others]. The use of mucosal gels in dentistry. Odessa, KP OGT, 2012: 20.

11. Gorokhovskiy VN, Denga OV, Denga AE [and others]. Modeling of orthodontic movement of teeth in rats. In book. Schneider SA, Levitsky AP "Experimental stomatology". Part 1. Experimental models of dental diseases. Odessa, 2017: 128-132.

12. Levitsky AP, Denga OV, Makarenko OA [and others]. Biochemical markers of inflammation of oral cavity tissue: method guidelines. Odessa, KP OGT, 2010: 16.

13. Levitsky AP, Makarenko OA, Selivanskaya IA [and others]. Enzymatic method for determining oral dysbiosis for screening pro and prebiotics: guidelines. Kiev, State Pharmacological Center, 2007: 22.

14. Levitsky AP, Makarenko OA, Denga OV [and others]. Experimental methods of research of stimulants of osteogenesis: methodical recommendations. Kiev, State Pharmacological Center, 2005: 50.

15. Levitsky AP, Makarenko OA, Khodakov IV [and others]. The enzymatic method of the estimation of the state of osseous tissue. Odessa Medical Journal. 2006; 3: 17-21.

16. Lapach SN, Chubenko AV, Babich PN Statistical methods in biomedical research using Excel. Kiev. Morion, 2000: 320. 
17. Levitsky AP, Tsiselsky Yu.V., Dem'yanenko SO [and others]. The use of prebiotics for the prophylaxis of stomatological complications in patients with diabetes mellitus: methodical recommendations. Odessa, KP OGT, 2010:18. 